\title{
SPECIES RICHNESS OF BEETLE (Hexapoda: Coleoptera) IN SURANADI NATURE RECREATION PARK, LOMBOK ISLAND
}

\author{
Mohammad Liwa Ilhamdi ${ }^{*}$, Agil Al Idrus ${ }^{1}$, Muhammad Syazali², and Ahmad Raksun ${ }^{1}$ \\ ${ }^{1}$ Biologi Education Program, University of Mataram, Mataram, Indonesia \\ ${ }^{2}$ Primary School Teacher Study Program, University of Mataram, Mataram, Indonesia \\ *Email: liwa_ilhamdi@unram.ac.id
}

Acceped: August 27 2021. Approved: Sept 01 2021. Published: Sept 042021

\begin{abstract}
This study aimed to determine the species richness of Hexapoda: Coleoptera in Suranadi Nature Recreation Park (NRP), Lombok Island, Indonesia. It is an exploratory, descriptive study with a qualitative method. Sample collection was carried out during May - July 2019 in three different habitats consisting of waterways along with the middle and edges of the forest. Sample collection was conducted using the pitfall trap method. The samples were identified at Biology Laboratory, Faculty of Teacher Training and Education, University of Mataram to obtain the species richness data. It was revealed that there were 11 species from 8 families of the Order Coleoptera. The species are Agonum micans, Trycorinus rudepunctatus, Euspilotus assimilis, Paracymus subcupreus, Phanaeus vindex, Myrmex sp., Dinopelma leptaleum, Oxyporus maxillosus, Oxylobus maridionalis, Tachys blandus and Platydema violacea.
\end{abstract}

Keywords: Species Richness, Coleoptera, Suranadi

\section{INTRODUCTION}

Suranadi Nature Recreation Park (NRP) is one of the conservation areas in West Lombok Regency and the Kerandangan NRP, Pelangan NRP, and Bangkobangko NRP. According to the Decree of West Lombok Regent [1], this area is included in Suranadi tourism village, with a 52 hectares area common characteristic. Despite being surrounded by urban areas that commonly have negative impacts on the ecology system [2-4], the naturalness of Suranadi NRP is still relatively well preserved. There is only very little non-biodegradable waste from the disobedient tourists that appeared on forest roads and rivers, which local field officers immediately clean. The role of local people in the preventing forest encroachment and destruction also contributes to preserving the naturalness of Suranadi NRP. Therefore, this area has an excellent environmental carrying capacity for the growth and development of various fauna such as mammals, aves, reptiles, amphibians, Pisces, and various hexapods [56], including beetle.

Based on taxonomy, the beetle is classified as a part of the order Coleoptera from superorder Endopterygota, infraclass Neoptera, and subclass Pterygota [7]. Coleoptera is divided into four suborders consisting of Archostemata, Adephaga, Myxophaga, and Polyphaga. Although This insect classification is less stable, at least 500 families are recorded. The common characteristic of this insect group has thick and hard hind wings due to the accumulation of chitin [8]. They have heterogeneous habitats and exist in almost all over the world except for the Arctic and Antarctic regions due to the snow all year round [9]. Order Coleoptera also cannot be found in the seawater. Instead, they live in freshwaters such as rice fields, rivers, and lakes [10]. To the best of current scientific knowledge,
Coleoptera has the highest species richness among the Hexapoda orders. The proportion is $40 \%$ of all existing insect species. There are about a total of 400 thousand species have been described worldwide [7]. This number continues to grow following the discovery of new species [11-13]. In Indonesia, the species richness of the Order Coleoptera is not precisely known. However, Noerdijto reported that about $10 \%$ of the total species in the world are identified as Coleoptera [14]. This proportion is likely to increase due to scientists' discovery of new species based on research in recent years [15-17]. Based on several studies, the number of species found is generally numbered in tens. For example, the known species richness of longhorn beetles (Coleoptera: Cerambycidae), playing an essential role in the ecosystem as bioindicators, saproxylate, pollinator, and prey for other organisms, has reached almost 72 species [18]. Other data show that the order Coleoptera of the family Elateridae has attained 59 species [19]. A study in 2020 conducted in one of the islands in the Lesser Sunda region indicated that the species found were represented by 27 families [20]. Various species of the order Coleoptera are scattered in Indonesia's various areas and islands, including Lombok Island. Based on the previous research, 43 species of beetles from Lombok Island have been recorded so far. This number refers to the research reports published from 2008 to 2015. Six species were representing five genera initially found in 2008 [21]. Those species are Lema (Petauristes) sumbawensis lomboki; Trichochrysea hirta Fabricius, 1801; Paraplotes granulata; Hespera foveipennis; Hespera lombokana and Nisotra insulana [22]. These data were obtained from the observations in Sesaot, Senaru and Sapit Sembalun. 26 additional species, which differ from previous findings, were successfully described [23]. A further 11 species later 
came from reports published in 2015 [24]. The total species ( 43 species) were represented by three families, namely Chrysomelidae (6 species), Staphylinidae (26 species), and Cerambycidae (11 species). This number is less than that in the most recent record, which is 27 families of Coleoptera [20]. The sampling was carried out in five locations, namely Pelangan, Tawung, Labuapi, Sesaot, and Jeruk Manis.

This finding indicates that there are still other species that remain unreported. In addition, there are still many unexplored potential areas, especially conservation areas that ecologically require important fauna data, including those from the order Coleoptera. One of the conservation areas is Suranadi NRP. To reveal the diversity potency, we conducted a preliminary study on order Coleoptera in Suranadi NRP. The purpose of this study was to list the species of the order Coleoptera. The results of this study can be used as primary data for research on other biodiversity parameters of the order Coleoptera in Suranadi NRP. The primary data from the results of this study can also be used by area managers and the other related parties for better conservation management to preserve the naturalness of biodiversity potency, especially those from the order Coleoptera. This report can positively impact the sustainability of the whole area since the fauna of the order Coleoptera is an essential component of the ecosystem [25-27]. Therefore, Suranadi NRP and any other Suranadi Tourism Village utilizing the ecological processes as the attraction are continuously maintained to drive the local community's economy. Finally, from the education aspect, the results of this study can be used as an alternative to science learning sources.

\section{RESEARCH METHOD}

\section{Time and Place of the Research}

It is an exploratory, descriptive study with a qualitative method. Research samples were collected during May - July 2020 in Suranadi NRP (Figure 1). The method used is the pitfall trap method [28]. A total of five traps were installed in each habitat type, including waterway along with the middle and edges of the forest. The trapping points are arbitrarily arranged based on the Quartile (Q) of each lane length. Trap 1 was placed at Quartile 1 (Q1), trap two was positioned at Q2, and so on until trap 5, located at Q5. The collected samples were identified in the laboratory to obtain species richness data of the order Coleoptera. Observations in the laboratory were carried out from August to December 2020.

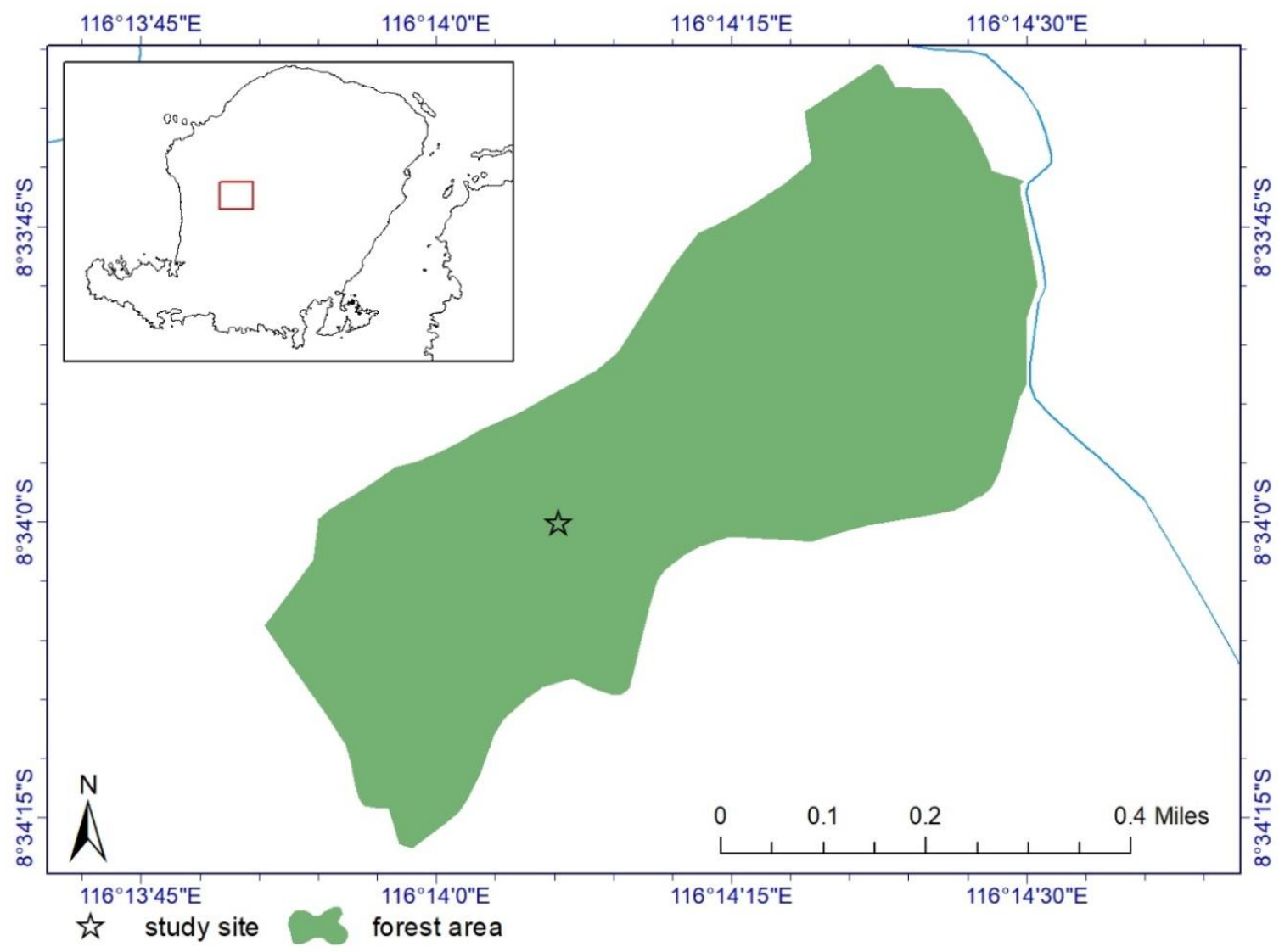

Figure 1. Research Location Map 


\section{Equipment and Materials}

There are several equipment and materials used in this research. The list of equipment and materials and their function during sample and data collection, is presented in Table 1 below.

Tabel 1. Equipment and materials, along with their function during the research.

\begin{tabular}{cll}
\hline No & Equipment and Materials & Function or Use \\
\hline Equipment: & \\
\hline 1 & Crowbar & Dig holes in the ground to spot Q1-Q5 \\
2 & Plastic cups $16 \mathrm{oz}$ & The main part of the trap \\
3 & Protective hood & Canopy of the trap \\
4 & Narmada plastic bottles & Storage for detergent solution \\
5 & Polypropylene plastic bag & Container to place the stuck sample in the trap \\
6 & Plastic bag & Keep polypropylene plastic bags containing samples \\
7 & Petri dish & Place the samples during observation in the laboratory \\
8 & Tweezers & Take and transfer samples \\
9 & Pasteur pipette & Reduce and take out the liquid from the petri dish \\
10 & Loupe & Observe small-sized samples \\
11 & Stereomicroscope & Observe small-sized samples \\
\hline 12 & Camera & Record research activities and findings \\
\hline Materials: & \\
\hline 13 & Formalin 4\% & Preserve trapped samples \\
14 & Aquadest & Dissolve the detergent \\
15 & Detergent & Reduces the surface pressure to drown trapped sample \\
16 & Spray paint & Mark locations or spots Q1-Q5 in each sampling path \\
17 & Alcohol 70\% & Clean the sample during observation in the laboratory \\
\hline
\end{tabular}

\section{Research Procedure}

The research was conducted in 3 stages. The first stage was preparation. This stage consisted of several activities, including (1) surveying the sampling location, (2) collecting the necessary tools and materials, and (3) preparing required accommodation and transportation. The second stage was sample collection. This stage was carried out in the Suranadi NRP area. Sample collection was conducted five times/replications. The time lag between replications was one week. The third stage was data collection. This stage was carried out in the biology laboratory, Biology Education Study Program, Faculty of Teacher Training and Education, University of Mataram. Data of species from the order Coleoptera were collected by identifying the morphological characteristics of the specimen. The identification of species refers to [29-31].

\section{RESULT AND DISCUSSION}

The use of 20 traps at three types of habitats in Suranadi NRP (5 in the waterway, 5 in the middle of the forest, and 5 on the left edge and 5 on the right edge of the forest) has successfully been used collected many species from the order Coleoptera. The total number of identified species is 11 species from 8 different families. The family Carabidae represents four species consisting of Agonum micans, Dinopelma leptaleum, Oxylobus meridionalis and Tachys blandus. Each of the other seven families represents one species. Trycorinus rudepunctatus from the family Anobiidae, Euspilotus assimilis from the family Histeridae, Paracymus subcupreus from the family Hydrophilidae, Phanaeus vindex from the family Scarabaeidae, Myrmex sp. from the family Curculionidae, Oxyporus maxillosus from the family Staphylinidae and Platydema violacea from the family Tenebrionidae. The complete information is presented in Table 2 below.

The number of species from the order Coleoptera found in Suranadi NRP is higher than those in Sesaot, Senaru, and Sembalun, only six species [21]. However, compared to the species composition observed in Pusuk, Bangko-bangko, Sesaot, Senaru, Sembalun (Sapit and Lawang), Batu Koq, and Pringgabaya [22], the number of species in Suranadi NRP is less. The total species recorded in various locations in Lombok Island are 26 species. In 2015, new species were discovered in equal numbers with the species in Suranadi NRP, 11 species [23]. Despite being found on the same island, Lombok Island, the difference in the number of species at different locations indicates the variation in environmental carrying capacity. In general, the environmental carrying capacity is positively correlated or directly proportional to the number of species. The carrying capacity of the environment refers to the availability of resources and conditions suitable for each species. Thus, the more suitable resources and environment available, the more species surviving that habitat. 
Table 2. Species composition of the Order Coleoptera found in Suranadi NRP

\begin{tabular}{cllccc}
\hline & & & \multicolumn{3}{c}{ Habitat type } \\
\cline { 3 - 5 } No & Family & Species & Waterway & $\begin{array}{c}\text { The Middle of } \\
\text { The Forest }\end{array}$ & $\begin{array}{c}\text { The Edge of The } \\
\text { Forest }\end{array}$ \\
\hline 1 & Carabidae & Agonum micans & + & - & - \\
2 & Anobiidae & Trycorinus rudepunctatus & + & - & - \\
3 & Histeridae & Euspilotus assimilis & + & - & - \\
4 & Hydrophilidae & Paracymus subcupreus & + & + & - \\
5 & Scarabaeidae & Phanaeus vindex & + & + & - \\
6 & Curculionidae & Myrmex sp & + & - & - \\
7 & Carabidae & Dinopelma leptaleum & + & - & - \\
8 & Staphylinidae & Oxyporus maxillosus & + & + & - \\
9 & Carabidae & Oxylobus meridionalis & + & - & + \\
10 & Carabidae & Tachys blandus & + & + & + \\
11 & Tenebrionidae & Platydema violacea & + & +
\end{tabular}

Note: $(+)=$ found; and $(-)=$ not found

It can be clearly observed in the difference in the species number in the three types of habitats in Mount Slamet [32]. This study specifically examined the biodiversity of the family Cerambycidae. There were 21 species found in the southern lane habitat. In the east lane habitat, 10 species were obtained. In the northern lane habitat, 17 species were observed. The effect of differences in environmental carrying capacity in the three habitat types was also observed from the species composition variable. This phenomenon occurs since each species of the order Coleoptera naturally chooses a habitat type based on the ecological niche. Therefore, populations of certain species can be found in different locations. For example, five species were found in all habitat types in the Harau Valley Nature Reserve, West Sumatra Province [33]. In Jambi, the number of species in two different forest types was different [34]. In Padang, namely the Biological Research and Educational Forest, two species were found only in one of the four existing habitat types [35]. Other evidence was documented from reports in Gede Pangrango National Park, Mount Walat Educational Forest, and Wehea Protection Forest [36-38]. In addition to external factors - environmental carrying capacity - the differences in the number of species in each habitat phenomenon is also closely related to the adaptability of the populations in the Coleoptera community. In Suranadi NRP, this factor affects differences in the local distribution of all species (Table 2).

The most adaptable species are Phanaeus vindex from the family Scarabaeidae, Oxylobus meridionalis from Carabidae, and Platydema violacea from the family Tenebrionidae because they can survive in all types of habitats which are waterway as well as the middle and edge of the forest. The species Paracymus subcupreus from the family Hydrophilidae were found in two habitats, namely waterway and the middle of the forest. Since many species are more sensitive, they only exist in one type of habitat: waterway. Agonum micans,
Trycorinus rudepunctatus, Euspilotus assimilis, Myrmex sp., Dinopelma leptaleum, Oxyporus maxillosus, and Tachys blandus. Other species in Lombok Island with high adaptability and wider ecological niches include Baeocera barda, Sapitia lombokiana and Lema (Petauristes) sumbawensis lomboki [21-22]. They can be found in the lowlands to the highlands of Mount Rinjani.

Based on the environmental carrying capacity factor, the most suitable habitat type for the life of the order Coleoptera is the waterway. All species can survive in this habitat (Figure 2), even though the length of this route is approximately 400 meters which is much smaller than the middle and edge of the forest lane. The environmental carrying capacity in the middle forest habitat can support the survival of four species, while that of the edge of the forest habitat can only support three species. The species surviving these two habitats were those with the highest adaptation, except for Paracymus subcupreus.

Another fact that could be an important finding in the study of the order Coleoptera in Lombok Island is that all species recorded in Suranadi NRP have never been reported before. This fact refers to reports published in the $2008-2015$ period [21-24]. From the family taxon, two families found in Suranadi NRP have not been listed in the report published in 2020 [20]. One family intersects with the 2008 - 2015 study results, while there are six families of those in the 2020 study. The intersecting families include Carabidae, Curculionidae, Hydrophilidae, Scarabaeidae, Staphylinidae, and Tenebrionidae. These facts contain at least three pieces of information, including (1) 11 species are becoming new records bringing the total known species of the order Coleoptera to be 54 species, (2) these species represent 29 taxon families in which there are two additional families namely Anobiidae and Histeridae, and (3) there are still unrecorded species, at 
J. Pijar MIPA, Vol. 16 No.4, September 2021: 535-541

DOI: $10.29303 /$ jpm.v16i4.2345

least from several families with unidentified species members.

Some other important information - niche of physical and chemical conditions - suitable to the species' life from Coleoptera in Suranadi NRP are presented in Table 3. The physical and chemical

Forest edge (3 specieses):

1. Phanaeus vindex

2. Oxylobus meridionalis

3. Platydema violacea

Middle forest ( 4 specieses):

1. Paracymus subcupreus

2. Phanaeus vindex

3. Oxylobus meridionalis

4. Platydema violacea
ISSN 1907-1744 (Print)

ISSN 2460-1500 (Online)

conditions consist of soil $\mathrm{pH}$, water temperature, air temperature, humidity, sunlight intensity, canopy, tree species richness, and herb cover. All species have a niche of interrelated physical and chemical conditions.

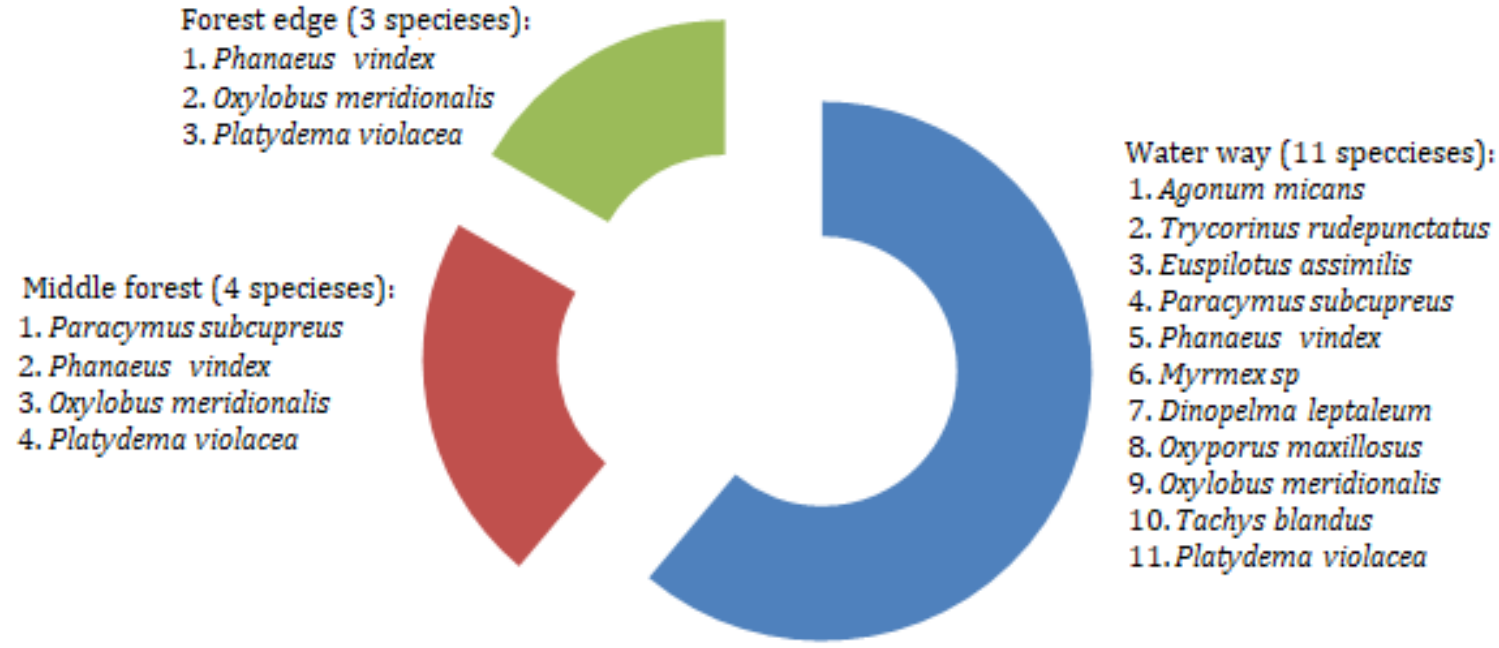

Figure 2. Species richness in each habitat type

Table 3. Physical and chemical conditions suitable for the life of the order Coleoptera

\begin{tabular}{lccccccc}
\hline \multirow{2}{*}{ Species } & \multicolumn{7}{c}{ Physical and Chemical Conditions of Habitat } \\
\cline { 2 - 8 } & LI & H & AT & TC & HPC & A & NoP \\
\hline Agonum micans & $65-275$ & $64-89$ & $27-34.3$ & $75-90$ & 91 & 256 & 35 \\
Trycorinus rudepunctatus & $65-275$ & $64-89$ & $27-34.3$ & $75-90$ & 91 & 256 & 35 \\
Euspilotus assimilis & $65-275$ & $64-89$ & $27-34.3$ & $75-90$ & 91 & 256 & 35 \\
Paracymus subcupreus & $31-275$ & $64-90$ & $26-34.3$ & $75-100$ & $80-91$ & $256-257$ & $15-35$ \\
Phanaeus vindex & $31-2800$ & $64-90$ & $26-34.3$ & $25-100$ & $50-91$ & $256-257$ & $15-35$ \\
Myrmex sp & $65-275$ & $64-89$ & $27-34.3$ & $75-90$ & 91 & 256 & 35 \\
Dinopelma leptaleum & $65-275$ & $64-89$ & $27-34.3$ & $75-90$ & 91 & 256 & 35 \\
Oxyporus maxillosus & $65-275$ & $64-89$ & $27-34.3$ & $75-90$ & 91 & 256 & 35 \\
Oxylobus meridionalis & $31-2800$ & $64-90$ & $26-34.3$ & $25-100$ & $50-91$ & $256-257$ & $15-35$ \\
Tachys blandus & $65-275$ & $64-89$ & $27-34.3$ & $75-90$ & 91 & 256 & 35 \\
Platydema violacea & $31-2800$ & $64-90$ & $26-34.3$ & $25-100$ & $50-91$ & $256-257$ & $15-35$ \\
\hline
\end{tabular}

Note: $\mathrm{LI}=$ light intensity $(\mathrm{Cd}), \mathrm{H}=$ humidity $(\%), \mathrm{AT}=$ air temperature $\left({ }^{\circ} \mathrm{C}\right), \mathrm{TC}=$ trees canopy $(\%), \mathrm{HPC}=$ herbaceous plant cover (\%), A = altitude (asl), NoP = number of plants.

Another study revealed that the population of Agonum micans was adaptive to abundant water conditions caused by flooding [39]. The high abundance proved it. Trycorinus roughpunctatus is a wood borer insect. The microhabitat is mainly dead wood [40]. It acts as a decomposer in the ecosystem. However, since it damages household furniture made of wood, this species is called a pest. Euspilotus assimilis can survive in $29-40{ }^{\circ} \mathrm{C}$ temperature and $4-67 \%$ humidity [41]. Paracymus subcupreus can be found in riverbanks and various types of shallow freshwater containing rich organic matter [42]. Phanaeus vindex could survive at lower temperatures than those measured in Suranadi $\mathrm{NRP}$, which is $10-25^{\circ} \mathrm{C}$ [43].

The variations in the ecological niche of each population from the order Coleoptera in Suranadi NRP suggest that conservation efforts in this area need to be adjusted by considering those variations. The good news is that the implemented conservation management system so far has been proven to successfully maintain the existence of Coleoptera in various types of habitats, at least for the 11 species recorded in this study. At the moment, macro-and micro-ecosystem conditions need to be maintained. Even if there is a change, the impact should not be significant. This change, for example, 
J. Pijar MIPA, Vol. 16 No.4, September 2021: 535-541

DOI: 10.29303/jpm.v16i4.2345

could be happened due to periodic natural factors as well as human activities such as physical development for tourism needs. Several things to be anticipated include (1) people who dispose of biodegradable waste carelessly, and (2) the behavior of the local community or community from other regions which have the potency to extremely damaging the condition of the area and therefore endanger the sustainability of the ecological system. Preventive efforts also need to be made to prevent or minimize the negative impacts of global climate change.

\section{CONCLUSION}

Species of the order Coleoptera found in Suranadi NRP consist of eleven species. Those species are Agonum micans, Trycorinus rudepunctatus, Euspilotus assimilis, Paracymus subcupreus, Phanaeus vindex, Myrmex sp, Dinopelma leptaleum, Oxyporus maxillosus, Oxylobus maridionalis, Tachys blandus and Platydema violacea. Eight families and 11 general represent the number of species. It is necessary to study the diversity aspect for further research to obtain more comprehensive data related to the order Coleoptera in Suranadi NRP.

\section{REFERENCES}

[1] West Lombok Regent Regulation No. 41 about Tourism Village Area. 2016. Government of West Lombok Regency, Gerung.

[2] Wang, Y., Bakker, F., De Groot, R., \& Wörtche, H. (2014). Effect of ecosystem services provided by urban green infrastructure on indoor environment: A literature review. Building and environment, 77, 88-100.

[3] Marando, F., Salvatori, E., Sebastiani, A., Fusaro, L., \& Manes, F. (2019). Regulating ecosystem services and green infrastructure: assessment of urban heat island effect mitigation in the municipality of Rome, Italy. Ecological Modelling, 392, 92-102.

[4] Kourdounouli, C., \& Jönsson, A. M. (2020). Urban ecosystem conditions and ecosystem services-a comparison between large urban zones and city cores in the EU. Journal of Environmental Planning and Management, 63(5), 798-817.

[5] Ilhamdi, M. L., Al Idrus, A., \& Santoso, D. (2018). Diversity of Species and Conservation Priority of Butterfly at Suranadi Natural Park of West Lombok, Indonesia. Biosaintifika: Journal of Biology \& Biology Education, 10(1), 48-55.

[6] Ilhamdi, M. L., Al Idrus, A, Santoso, D., Hadiprayitno, G., \& Syazali, M. (2021). Species richness and conservation priority of dragonflies in the Suranadi Ecotourism Area, Lombok, Indonesia. Biodiversitas Journal of Biological Diversity, 22(4). 1846-1852.
ISSN 1907-1744 (Print)

ISSN 2460-1500 (Online)

[7] Gilliott, Cedric (1995). Entomology (2 ${ }^{\text {nd }}$ edition). Springer-Verlag New York, LLC. hlm. 96. ISBN 0-306-44967-6.

[8] Carpenter, George Herbert (1899). Insects, Their Structure and Life.

[9] Gullan, P.J. (2010). The Insects: An Outline of Entomology (4 ${ }^{\text {th }}$ edition). Oxford: Wiley, John \& Sons, Incorporated. ISBN 1-4443-3036-5.

[10] Ghalley, T. B., Dorji, U., Dorji, C., Nepal, A., \& Shacha, N. (2021). Water Beetles: Species Diversity and Response to Physico-Chemical Parameters in Different Freshwater Habitats in Samtse, Bhutan. International Journal of Environment, 10(1), 64-82.

[11] Tshernyshev, S. E., \& perkovsky, E. E. (2021). Protomauroania mikhailovi-a new species of malachite beetles (Coleoptera, Dasytidae) in Rovno amber. Zootaxa, 5006(1), 189-194.

[12] Konstantinov, A. S. (2021). Flea beetles of the West Indies: new combinations and new species (Coleoptera: Chrysomelidae: Galerucinae: Alticini). Journal of Insect Biodiversity, 25(1), 127.

[13] Jr, F. Č., Kodada, J., Bozáňová, J., \& ČiamporováZat'ovičová, Z. (2021). Disersus otongachi a new species of Larainae riffle beetles from Ecuador (Coleoptera: Elmidae). Zootaxa, 4963(1), 193-199.

[14] Shahabuddin, S., Hidayat, P., Noerdjito, W. A., \& Manuwoto, S. (2005). Research on insect biodiversity in Indonesia: Dung beetles (Coleoptera: Scarabaeidae) and its role in ecosystem. Biodiversitas Journal of Biological Diversity, 6(2), 141-146.

[15] Kirschenhofer, E. (2010). New and little-known species of Carabidae from the Middle East and Southeast Asia (Coleoptera, Carabidae: Lebiini, Brachinini). In Annales Historico-Naturales Musei Nationalis Hungarici (Vol. 102, pp. 25-64).

[16] Makihara, H., \& Noerdjito, W. A. (2011). Longicorn beetles from Mts. Bromo in East Java, Indonesia, with descriptions of a new species and a new subspecies (Coleoptera; Cerambycidae). Bulletin of the Forestry and Forest Products Research Institute, Ibaraki, (421), 251-261.

[17] Bui, V. B., Ziegler, T., \& Bonkowski, M. (2019). Checklist of beetles in the subgenus Copris (Paracopris) Balthasar from Asia with description of a new species, and redescription of Copris (Paracopris) punctulatus Wiedemann (Coleoptera: Scarabaeidae: Scarabaeinae). Zootaxa, 4712(1), zootaxa-4712.

[18] Atmowidi, T., \& Noerdjito, W. A. (2016). Diversity and abundance of cerambycid beetles in the four major land-use types found in Jambi Province, Indonesia. HAYATI Journal of Biosciences, 23(2), 56-61. 
J. Pijar MIPA, Vol. 16 No.4, September 2021: 535-541

DOI: 10.29303/jpm.v16i4.2345

[19] Nazarreta, R., Hidayat, P., \& Buchori, D. (2020, March). Diversity and species composition of click beetles (Coleoptera: Elateridae) at different landuse types in Harapan Rainforest landscape, Jambi, Indonesia. In IOP Conference Series: Earth and Environmental Science (Vol. 468, No. 1, p. 012015). IOP Publishing.

[20] Rohyani, I. S. (2020). Community structure analysis of soil insects and their potential role as bioindicators in various ecosystem types in Lombok, West Nusa Tenggara, Indonesia. BIODIVERSITAS, 21(9), 4221-4227.

[21] Medvedev, L. N. (2008). New and poorly known Chrysomelidae (Coleoptera) from the islands of Bali and Lombok (Indonesia). Stuttgarter Beiträge zur Naturkunde A, Neue Serie, 1, 431-434.

[22] Löbl, I. (2020). On the Scaphidiinae (Coleoptera: Staphylinidae) of the Lesser Sunda Islands. Revue suisse de zoologie, 122(1), 75-120.

[23] Yokoi, Y. (2015). Notes on the Callidiopini (Coleoptera, Cerambycidae) across the Lombok Strait. Elytra (n. ser.), 5(1), 185-205.

[24] Niisato, T., \& Yokoi, Y. (2015). Additional Notes on the Stenopterine Fauna (Coleoptera, Cerambycidae) of the Island of Lombok, Indonesia.

[25] Candra, B., Monfalcone, S., Lydeard, C., \& O'Keefe, S. (2021). Preliminary Study on Beetle Biodiversity and Its Role As A Metric For Ecosystem Heterogeneity In The Rowan County Area.

[26] Wetherbee, R., Birkemoe, T., Burner, R. C., \& Sverdrup-Thygeson, A. (2021). Veteran trees have divergent effects on beetle diversity and wood decomposition. PloS one, 16(3), e0248756.

[27] Sarmiento-Garcés, R., \& Hernández, M. I. M. (2021). A decrease in taxonomic and functional diversity of dung beetles impacts the ecosystem function of manure removal in altered subtropical habitats. PloS one, 16(1), e 0244783.

[28] Kim, D., Cho, Y. B., Kim, J. L., jeong Hong, E., Kim, C., Cha, J. Y., \& Han, Y. G. (2021). Analysis of capture efficiency of pitfall traps for the National Ecosystem Survey of Korea. Journal of AsiaPacific Biodiversity.

[29] Borror, D. J., Triplehon, C.A., and Johnson, N. F. (1992). Pengenalan Pelajaran Serangga (Yogayakarta: Gadjah Mada University Press) Sixth edition.

[30] Dindal, D. L. (Ed.). (1990). Soil biology guide (No. 631.46 D5). New York: Wiley.

[31] Harding, W. A., \& Moore, J. P. (1926). The Fauna of British India, including Ceylon and Burma (Vol. $3)$. Today and Tomorrow Publisher.

[32] Noerdjito, W. A. (2011). Evaluasi kondisi hutan berdasarkan keragaman kumbang sungut panjang
ISSN 1907-1744 (Print)

ISSN 2460-1500 (Online)

(coleoptera, cerambycidae) di Kawasan Gunung Slamet. Berita Biologi, 10(4), 521-531.

[33] Putri, R., \& Herwina, H. (2014). Jenis-Jenis Kumbang Tinja (Coleoptera: Scarabaeidae) di Kawasan Cagar Alam Lembah Harau, Sumatera Barat. Jurnal Biologi UNAND, 3(2), 135-140.

[34] Kasmiatun, K., Nazarreta, R., \& Buchori, D. (2020). Keanekaragaman dan komposisi kumbang elaterid (Coleoptera: Elateridae) di kawasan hutan hujan tropis Taman Nasional Bukit Duabelas dan Hutan Harapan, Jambi. Jurnal Entomologi Indonesia, 17(1), 33-33.

[35] Sari, Y. I., Dahelmi, D., \& Herwina, H. (2015). Jenis-Jenis Kumbang Tinja (Coleoptera: Scarabaeidae) di Hutan Pendidikan dan Penelitian Biologi (HPPB) Universitas Andalas, Padang. Jurnal Biologi UNAND, 4(3), 193-199.

[36] Kahono, S., \& Kundarsetiadi, L. (2007). Distribusi vertikal kumbang tinja Scarabaeidae (Coleoptera: Scarabaeidae) di hutan tropis basah pegunungan Taman Nasional Gede-Pangrango, Jawa Barat. Berita Biologi, 8(5), 325-333.

[37] Sataral, M. I. H. W. A. N. (2015). Keanekaragaman dan kelimpahan kumbang antena panjang (Coleoptera: Cerambycidae) di Hutan Pendidikan Gunung Walat, Jawa Barat. Institut Pertanian Bogor. Bogor.

[38] Forest, W. P. (2018). Keanekaragaman kumbang sungut panjang (Coleoptera: Cerambycidae) di Hutan Lindung Wehea, Kalimantan Timur. Jurnal Entomologi Indonesia, 15(3),166-176.

[39] Sienkiewicz, P., \& Żmihorski, M. (2012). The effect of disturbance caused by rivers flooding on ground beetles (Coleoptera: Carabidae). European Journal of Entomology, 109(4), 535-541.

[40] Ceruti, F. C., Lazzari, S. M. N., \& Neto, G. H. R. (2010). Tricorynus rudepunctatus (Pic) (Coleoptera: Anobiidae): diagnosis and damage. Julius-Kühn-Archiv, 425, 91-96.

[41] Bala, M., \& Kaur, P. (2014). Insect faunal succession on buried piece of pork in the state of Punjab (India): A preliminary study. J. Forensic Res, 5(6), 1-4.

[42] Hilsenhoff, W. L. (2017). Aquatic Hydrophilidae and Hydraenidae of Wisconsin (Coleoptera). II. Distribution, Habitat, Life Cycle and Identification of Species of Hydrobiini and Hydrophilini (Hydrophiudae: Hydrophilinae). The Great Lakes Entomologist, 28(2), 97-126.

[43] Sheldon, K. S., Padash, M., Carter, A. W., \& Marshall, K. E. (2020). Different amplitudes of temperature fluctuation induce distinct transcriptomic and metabolomic responses in the dung beetle Phanaeus vindex. Journal of Experimental Biology, 223(23), jeb233239. 